\title{
HUBUNGAN SIKAP MALAS DAN PROKRASTINASI AKADEMIK PADA MAHASISWA
}

\author{
Reysuna Karunia Putri \\ S1 Psikologi Universitas Lambung Mangkurat \\ Banjarbaru, Indonesia \\ 2010914220032@mhs.ulm.ac.id
}

\begin{abstract}
Abstraksi
Penulisan artikel ini dilakukan untuk mengetahui hubungan antara sikap malas dan prokrastinasi pada mahasiswa, faktor yang menyebabkan sikpa malas, dan bagaimana kita menanggapi sikap malas tersebut. Metode yang digunakan adalah kajian literatur menggunakan artikel dan dua buku. Dengan hasil bahwa adanya keterkaitan antara sikap malas dan prokrastinasi mahasiswa, di mana sikap malas itu dipengaruhi oleh faktor internal dan eksternal. Bagaimana kita menyikapinya adalah semua tergantung pada diri masing-masing ingin mengubahnya atau tidak, Saya mengangkat tema ini karena fenomena penundaan pengerjaan tugas oleh mahasiswa yang kebanyakan didasari pada rasa malas, bahkan saya sendiri merasakannya.
\end{abstract}

Keywords: Sikap malas; Prokrastinasi pada mahasiswa

\section{PENDAhULUAN}

Kaum rebahan. Kalimat itu menjadi istilah di masyarakat untuk mereka yang senang rebahan. Tidak hanya itu, kaum rebahan digadang-gadang juga sebagai sebutan bagi orang-orang yang suka bermalas-malasan. Alasan nomor satunya adalah 'mager'. Mager adalah singkatan dari malas gerak (dalam Abbas \& Erlyani, 2020).

\section{Pengertian Malas}

Menurut Malas adalah perilaku seseorang yang cenderung tidak aktif dan kurang semangat dalam melakukan aktivitas (Bella \& Ratna, 2018). Sifat malas adalah dampak dari kurangnya kecakapan dalam mengatur waktu dan kurangnya disiplin diri, bukan dari faktor genetik (Bella \& Ratna, 2018). Dalam buku Kamus Lengkap Bahasa Indonesia oleh M.K. Abdullah, malas memiliki arti enggan, segan.

Saat pemerintah menetapkan bahwa perkuliahan akan dilakukan secara daring, mahasiswa merasa seperti diberi angin segar sebab mereka terlepas dari kukungan universitas, tidak perlu datang ke kampus tepat waktu, dapat berpakaian bebas, atau tidak perlu capai ke sana kemari mencari bahan research. Semua dilakukan di rumah bahkan bisa sambil rebahan. Itu bisa menjadi penyebab dari kemalasan mahasiswa. Intensitas memegang gawai yang semakin meningkat karena semua dilakukan secara daring juga menjadi pendukung tingkat kemalasan mahasiswa. Saat sedang berselancar di internet untuk mencari materi, denting notifikasi media sosial tidak bisa diabaikan. Dengan cepat jari menggulir layar hingga tidak terasa waktu berjam-jam habis hanya untuk scrolling medsos. Lalu saat menyadari waktu dan merasa lelah, akan lahir kalimat "Ah, besok aja deh, deadline nya masih lama", mulai saat itu penundaan tugas terjadi.

Salah satu bentuk kemalasan mahasiswa adalah menunda tugas. Fleksibilitas waktu yang diberikan oleh dosen kepada mahasiswa terkadang justru disalahartikan hingga menjadi pemicu penundaan tugas. Tidak sedikit mahasiswa yang meremehkan tugas pemberian dosen, mereka lebih memilih menghabiskan waktu untuk bersenang-senang dan mengesampingkan tugas dengan dalih masih banyak waktu yang tersedia (Fauziah, 2015). Dengan pemikiran seperti itu, mahasiswa akan cenderung mengerjakan tugas 
mendekati tenggat waktu. Hal ini disebut Prokrastinasi.

\section{Pengertian Prokrastinasi}

Kata prokrastinasi berasal dari bahasa latin yaitu Pro dan Crastinus, di mana pro berarti bergerak ke depan (forward motion) dan crastinus berarti milik hari esok (belonging to me). Dalam ilmu psikologi, prokrastinasi adalah tindakan menunda tugas berkepentingan tinggi dengan tugas berkepentingan rendah sehingga tugas penting tersebut terabaikan. Steel dalam Tan, Ang, dkk (2008) menyebutkan bahwa prokrastinasi akademik adalah secara sengaja menunda tugas akademik dalam kurun waktu tertentu. Ferrari, Johnson, dan McGown (1995) mengatakan bahwa kata prokrastinasi sering digunakan dalam banyak naskah Latin dengan pemaknaan positif yaitu memutuskan untuk bersabar dalam pengambilan keputusan yang matang dan menunggu saat yang tepat hingga musuh keluar dalam konflik politik. Barulah di abad ke-18, saat industrialisasi, prokrastinasi dimaknai sebagai sesuatu yang negatif karena semakin menjalarnya tenggat waktu. Vestervelt (2000) menyebutkan bahwa seseorang tidak dianggap melakukan prokrastinasi apabila mengingat tenggat waktu dan tidak sadar sedang melakukan penundaan, serta prokrastinasi haruslah diikuti dengan afeksi negatif (Darmawan, 2017).

\section{ASPEK PROKRASTINASI}

Pertama, perceived time (Ferrari,
Johnson, \& McGown, 1995) yaitu
kecenderungan gagal menepati tenggat waktu
akibat orang tersebut lebih berorientasi pada
apa yang terjaadi saat ini dan tidak
memperkirakan apa yang terjadi di masa
mendatang.

Kedua, intention-action gap (Steel, 2007) yaitu ketimpangan antara keinginan dan tindakan. Semakin mendekati tenggat waktu, semakin kecil tingkat ketimpangannya.

Ketiga, Emotional Distress (Stell, 2007) yaitu perasaan tidak nyaman akan dampak yang didapatkan saat melakukan prokrastinasi.
Keempat, perceived ability (Ellis \& Knaus, disirat dalam Steel, 2007). Ragu akan kemampuan yang dimiliki bisa menjadi pemicu seseorang melakukan prokrastinasi. Saat ia merasa tidak mampu dalam mengerjakan tugasnya maka ia akan menghindarinya dengan menunda pengerjaan tugas tersebut. Namun perlu diperhatikan, jika kasusnya adalah saat seseorang telah mencoba mengerjakan tugas sedari awal tapi karena soal begitu sulit hingga mencapai tenggat waktu ia tidak bisa memenuhinya maka itu tidak termasuk dalam perilaku prokrastinasi. Menurut Steel (2003b), kemampuan (ability) tidak termasuk dalam pengukuran prokrastinasi (Tjundjing, 2006).

Salah satu aspek kepribadian dari Big Fie Theory yang sudah teruji memiliki korelasi signifikan tinggi denga prokrastinasi adalah Conscientiousness (Surijah \& Tjundjing, 2007). Seseorang yang memiliki kepribadian Conscientiousness adalah seseorang yang penuh perencanaan. Conscientiousness dapat dikatakan juga sebagai condong berperilaku teratur, bertanggung jawab, dan pekerja keras (Surijah \& Tjundjing, 2007). Seseorang dengan kepribadian ini saat mengerkajan tugas maka ia akan fokus dengan tugas yang dikerjakannya dan mengesampingkan hal lain.

Levy dan Ramim (2012) melakukan penelitian kepada 1.629 mahasiswa Amerika mengenai perilaku prokrastinasi dengan hasil 58\% mahasiswa melakukan prokrastinasi dalam menyelesaikan tugasnya. Burka dan Yuen (dalam Senecal, Koestner, \& Vallerant, 1995) mengatakan bahwa yang memiliki problem prokrastinasi sering terkait dengan kerpibadian yang buruk seperti malas, kurang disiplin, atau tidak dapat mengatur waktunya (dalam Febritama \& Sanjaya, 2018).

Dalam tulisan saya kali ini, akan dibahas mengenai prokrastinasi dalam definisi negatif yaitu prokrastinasi akademik. Tujuan penulisan saya ini dimaksudkan agar kita (1) Mengetahui hubungan antara rasa malas dan prokrastinasi pada mahasiswa, (2) Penyebab rasa malas pada mahasiswa, dan (3) Bagaimana seharusnya menyikapi rasa malas tersebut.

\section{METODE}


Artikel ini saya buat dengan pendekatan kualitatif menggunakan metode kajian literatur. Data berasal dari artikel dan jurnal yang terdapat di google scholar dan ppjp ulm, kemudian dianalisis dan dikompilasikan hingga menghasilkan kesimpulan yang disajikan dalam artikel ini.

\section{HASIL DAN PEMBAHASAN}

Salah satu penyebab mahasiswa melakukan prokrastinasi berasal dari internal problem nya yaitu adanya rasa malas yang timbul akibat kurangnya motivasi dan lebih tertarik untuk melakukan hal-hal yang lebih menyenangkan seperti bermain game online atau menonton drama. Motivasi yang dimaksudkan di sini adalah motivasi belajar pada mahasiswa. Motivasi belajar ialah suatu kondisi dalam diri mahasiswa yang memacu dan merujuk perilaku mahasiswa untuk mencapai tujuan dalam menuntut ilmu (Arumawati, 2019). Seorang mahasiswa yang memiliki motivasi belajar akan menyempatkan waktunya untuk belajar lebih banyak dan bersungguh-sungguh, kemudian muncul dorongan dari dalam dirinya untuk melakukan aktivitas atas kemauannya seperti menyelesaikan tugas tepat waktu. Menurut Herzberg, hajat akan penghargaan dan manifestasi diri menjadi faktor intrinsik dalam motivasi seseorang. Ketika seorang mahasiswa memiliki keinginan untuk memperoleh nilai A dalam suatu mata kuliah maka ia akan berusaha untuk terus menjadi lebih baik agar tujuannya tercapai, ia memotivasi dirinya dengan menjadi yang terbaik, salah satunya dengan menyelesaikan tugas tepat waktu. Dengan adanya motivasi maka seorang mahasiswa akan lebih bersemangat dan enjoy dalam penyelesain tugasnya sehingga rasa malas itu tersisihkan.

Selain motivasi belajar, faktor apa saja yang memperngaruhi mahasiswa hingga bersikap malas dalam menyelesaikan tugasnya? Rasa malas itu bisa timbul dari faktor internal maupun eksternal. Penyesuaian mahasiswa terhadap lingkungan kedewasaannya juga mampu menimbulkan rasa jenuh dan malas jika tidak berjalan dengan baik. Faktor internal yang pertama, kondisi psikis mahasiswa. Keadaan perasaan, minat, kecerdasan, jenuh belajar, dan habit dalam belajar. Kurangnya motivasi diri seperti yang saya sebutkan di atas mampu menjadikan mahasiswa kurang bersemangat. Kedua yaitu fisiologi. Kesehatan fisik tentu juga penting, tidak hanya otak tapi tubuh juga bekerja dan sangat pasti mengalami kelelahan. Aktivitas yang padat membuat mahasiswa lebih memilih mengistirahatkan tubuhnya terlebih dahulu sebelum mengerjakan tugasnya, tetapi saat mahasiswa sudah kebablasan istirahat ia cenderung malas untuk beranjak dari posisinya dan mulai membuang waktunya untuk hal yang lebih membuatnya nyaman. Kekurangan nutrisi yang menyebabkan tubuh letih lesu juga menjadi faktor fisiologi dalam kemalasan mahasiswa. Ketiga, tidak mampu mengatur waktu. Saat mahasiswa tidak mampu memperkirakan waktu untuk menyelesaikan tugas ia akan bersikap santai dan bermalasmalasan dengan banyaknya waktu yang diberikan. Karena pelaku prokrastinasi cenderung berorientasi pada 'saat ini'.

Kemudian faktor eksternal yang mempengaruhi kemalasan mahasiswa. Kondisi sekitarnya yang tidak kondusif seperti gangguan dari adik saat hendak mengerjakan tugas dan godaan-godaan seperti film baru, novel yang belum selesai dibaca dan sebagainya yang mempengaruhi mahasiswa dalam bersikap malas. Kemudian waktu, ada mahasiswa yang waktu aktifnya adalah malam, ada juga mahasiswa yang kerja otaknya berjalan lancar saat siang hari. Temperature udara dan fasilitas belajar juga mempengaruhi kemalasan mahasiswa dalam penyelesaia tugasnyan. Dosen pun juga mampu mempengaruhi kemalasan seorang mahasiswa. Saat dirasa ia kurang 'klik' dengan penjelasan dosen tersebut hingga ia kurang memahami materinya, akan timbul rasa malas untuk mengerjakan tugas. Kompetensi pedagogik dosen juga mempengaruhi tingkat motivasi belajar seorang mahasiswa agar tidak malas. Kompetensi pedagogik adalah keterampilan dosen dalam mengelola pembelajaran. Semakin tinggi kompetensi pedagogik dosen maka semakin meningkat motivasi belajar mahasiswa. 
Dalam menyikapi rasa malas tersebut, tentu yang paling penting adalah keinginan dalam diri sendiri untuk menjadi lebih baik. Regulasi diri adalah kecakapan seseorang dalam meuntun perilaku diri sendiri untuk mencapai tujuannya (Febritama \& Sanjaya, 2018). Seorang mahasiswa yang mempunyai regulasi diri yang baik mampu memfokuskan dirinya untuk mencapai tujuan dan menghindari gangguan-gangguan yang dapat membuat dirinya lengah dari tujuan tersebut. Dikatakan juga bahwa seseorang yang memiliki regulasi tinggi secara tidak sadar ia juga memiliki sikap perfeksionisme (dalam Rohimah, dkk, 2016). Perfeksionisme menurut Hewitt dan Flett (1991) adalah suatu tindakan atau sikap untuk tidak melakukan kesalahan dalam mencapai kesempurnaan dalam setiap aspek kehidupan individu (dalam Rohimah, dkk, 2016). Kemudian tidak bosan-bosannya saya katakan bahwa motivasi menjadi hal yang penting dalam mengatasi rasa malas. Saat seseorang sudah mengetahui motivasinya, ia akan berusaha keras dan tidak membuang barang sedetik pun waktu agar tujuannya tercapai. Motivasi mendorong seseorang untuk melakukan kegiatannya. Perlu juga adanya komitmen mahasiswa terhadap tugas yang dikerjakan agar tidak terjadi keterlambatan pengumpulan. Sedangkan faktor ekternal seperti penghargaan dari orang lain hanyalah pendukung dalam menanggulangi rasa malas dalam menuntaskan tugas, semua keputusan akan kembali pada diri sendiri. Sesungguhnya tidak ada alasan untuk tidak menjadi lebih baik, tidak ada alasan untuk malas (dalam Abbas, 2020). Semua dari kita harus bisa mengatur waktu, tenaga, kemampuan, dan sebagainya agar tidak dijadikan alasan untuk tidak taat aturan.

Lalu apakah prokrastinasi yang disebabkan oleh rasa malas akan menimbulkan dampak? Dari hasil penelitian oleh Tjundjing (2006), ditemukan korelasi negatif antara prokrasinasi dengan prestasi, jadi dapat dikatakan bahwa prokrastinasi tidak berdampak pada prestasi seseorang. Namun, jika prokrastinasi dilakukan bukan karena untuk menurunkan kecemasan, tentu saja prokrastinasi memiliki dampak negatif jangka panjang berupa penurunan kinerja seseorang dan menimbulkan efek bagi psikis dan kesehatan fisik (van Eerde, 2003; Steel, 2003).

\section{KESIMPULAN}

Berdasarkan pembahasan di atas maka dapat disimpulkan bahwa sikap malas seorang mahasiswa mempengaruhi sikap prokrastinasi. Sikap malas yang diakibatkan oleh faktor internal dan eksternal seorang mahasiswa terutama tidak adanya motivasi untuk mencapai tujuannya menjadi pendorong mahasiswa berperilaku prokrastinasi. Lalu cara menanggulanginya adalah tergantung pada diri sendiri ingin mengubah sikap malas itu atau tidak. Meningkatkan regulasi diri menjadi salah satu caranya dan tidak ada alasan untuk seseorang menjadi malas dan tidak ingin berubah menjadi lebih baik.

\section{DAFTAR PUSTAKA}

Abbas, E. W., \& Erlyani, N. (2020). Menulis di Kala Badai Covid-19.

Bella, M. M., \& Ratna, L. W. (2018). Perilaku Malas Belajar Mahasiswa di Lingkungan Kampus Universitas Trunojoyo Madura. Competence: Journal of Management Studies, 12(2).

Fauziah, H. H. (2015). Fakor-faktor yang mempengaruhi prokrastinasi akademik pada mahasiswa fakultas psikologi uin sunan gunung djati bandung. Psympathic: Jurnal Ilmiah Psikologi, 2(2), 123-132.

Tjundjing, S. (2006). Apakah Prokrastinasi Menurunkan Prestasi? Sebuah MetaAnalisis. Anima, Indonesian Psychological Journal, 22(1), 17-27.

Darmawan, O. (2017). HUBUNGAN STRES AKADEMIK DAN EFIKASI DIRI DENGAN PROKASTINASI AKADEMIK MAHASISWA ANGKATAN 2009-2012 FAKULTAS ILMU SOSIAL DAN ILMU POLITIK UNIVERSITAS BRAWIJAYA. Skripsi Jurusan Psikologi-Fakultas Pendidikan Psikologi UM. 
Febritama, S., \& Sanjaya, E. L. (2018). Hubungan antara Regulasi Diri Dengan Perilaku Prokastinasi Akademik Pada Mahasiswa, $5(2), \quad$ doi: http://dx.doi.org/10.20527/ecopsy.v5i2.51 $\underline{78}$

Arumawati, S. (2019). Kontribusi Layanan Penguasaan Konten dan Motivasi Belajar Terhadap Prokrastinasi Akademik Siswa Kelas X di SMAN 5 Banjarmasin, 2(2), diakses di: ppjp.ulm.ac.id

Pujadi, A. (2007). Faktor-faktor yang mempengaruhi motivasi belajar mahasiswa: studi kasus pada fakultas ekonomi universitas bunda mulia. Business Management Journal, 3(2).

Nitami, M., Daharnis, D., \& Yusri, Y. (2015). Hubungan motivasi belajar dengan prokrastinasi akademik siswa. Konselor, $4(1), 1-12$.

Rohimah, S., Mayangsari, M. D., \& Fauzia, R. (2016). Hubungan Regulasi Diri dalam Belajar dengan Perfeksionisme pada Siswa SMA Boarding School. Jurnal Ecopsy, 2(3).

Rachmah, D. N., Mayangsari, M. D., \& Akbar, S. N. (2015). Motivasi belajar sebagai mediator hubungan kecerdasan adversitas dan prokrastinasi akademik pada mahasiswa yang aktif berorganisasi. Jurnal Cakrawala Pendidikan, 34(2).

Rahman, A. M., Mutiani, M., \& Putra, M. A. H. (2019). Pengaruh kompetensi pedagogik dosen terhadap motivasi belajar mahasiswa pendidikan IPS. Jurnal Darussalam: Jurnal Pendidikan, Komunikasi dan Pemikiran Hukum Islam, 10(2), 375-387.

Amini, M., Mayangsari, M. D., Zwagery, R. V. (2019). Hubungan Kemandirian Belajar Dengan Komitmen Tugas Pada Mahasiswa Program Studi Psikologi, 2(2), diakses di: ppjp.ulm.ac.id

WARMANSYAH ABBAS, E. R. S. I. S. (2020). Menulis di Era Covid-19: Memanage Trauma Psikologis
Menghindari Psikosomatis. Menulis di Era Covid-19: Memanage Trauma Psikologis Menghindari Psikosomati

Surijah, E. A., \& Tjundjing, S. (2007). Mahasiswa versus tugas: prokrastinasi akademik dan conscientiousness. Anima, Indonesian Psychological Journal, 22(4), 352-374. 
